\title{
Economic Development and the Demand in Global Business toward Business Markets
}

 \\ ${ }^{1}$ Faculty of Economics, FON University, Macedonia \\ ${ }^{2}$ Department of International Economic Relations and Business, University of National and World Economy, Bulgaria
}

Copyright $(2016$ by authors, all rights reserved. Authors agree that this article remains permanently open access under the terms of the Creative Commons Attribution License 4.0 International License

\begin{abstract}
Economic development is the most important for foreign consumers to adjust their trade tasks and demand in global business. Each stage of the economic development of a country has a powerful impact on prospects of foreign investment activities, commodity demand, the permanent system of distribution and logistics and a comprehensive marketing process while increasing consumption. Basically, economic development represents a double challenge. Firstly, there is a need to investigate general aspects to gain an image of the economic climate. Secondly, each state of economic growth must be investigated with the focus being on market opportunities, current economic level and growing economic potential. The state of economic development at a particular moment determines the kind and level of market potential. Economic dynamics and economic competence make it possible for commerce to prepare and respond appropriately to economic movements and market development. Economic growth is perceived and explored by the authors in terms of increased national production resulting in increased GDP per capita in domestic production but with a wide distribution of increased income, where there are conditions and aspirations towards gross economic growth, increased consumer demand and requirements which are likely to get higher with every decade as opposed to the process stretching over centuries in the past.
\end{abstract}

Keywords Economics, Economic Development, Consumer Markets, Industrial Markets, Market Potential, Growth

\section{Introduction}

The model of economic development and global trade, which is successfully making its way to the $21^{\text {st }}$ century, has proven its principles. The model consists of three multinational market regions which are parts of three larger groups such as Europe, Asia and the USA, where business is made with highly developed countries such as Germany,
Japan and the USA; but also with Brazil, Mexico, Poland and South Korea which are still developing, as well as with other emergent markets keeping up with these trends. [1]

Outside the model of economic development of Europe, Asia and the USA, there are different levels of development. These countries tend to be supported by their prosperous neighboring countries - India, Indonesia, Malaysia, Thailand, and the Philippines. They are following in the footsteps of the leading countries. Together, these four groups create a vast and strong global market in which global businesses are interwoven with the aim of improving their prospective business markets.

Economic development, demand of global market businesses and expansion of business market require each country not to settle for the status it has gained but to keep insisting on better standards of living and business environment. Opportunities for better life are perceived as part of the global world of consumers. According to WTO, the trade of the USA, China and other emerging markets is predicted to increase by $75 \%$ of the world growth from the next decade until 2025. [2]

The main purpose of this paper is to analyze the marketing changes that occur as a result of the economic development. It also aims at explaining the differences between the changes of the industrial and the consumer markets.

\section{Methodology}

The conceptual framework of the paper is based on secondary research. It uses as a starting point the Rostow's model of economic growth. [3] The discussion marks milestones which result from comparative analysis, induction and deduction. The authors also use their observations from an empirical study devoted to the international competitiveness of the industrial sectors in their countries. [4] The conclusions summarize the importance of the marketing knowledge about the specifics of the industrial and consumer markets. 


\section{Economic Development}

The most important factor of economic development which affects the international market of industrial goods and services is the degree of industrialization. Despite the fact that the generalization across countries is virtually always independent, the degree of economic development can be used as an approximate measurement method when determining the industrial market of a country. We would like to refer to the Rostow's 5-stage model of economic growth. [3] The demand for industrial goods and services can be classified accordingly. Each stage represents the function of labor price, consumer technical ability, operation scope, interest rate and product subtleness. The growth achieved through going one step further, from one stage to another, indicates the transition and confirmation of economic growth through the following stages.

Traditional Society. The important industrial demand will be associated with natural resources extraction as a result of a low productivity level and a lack of a systematic application of contemporary scientific and technological methods.

Preconditions for Take-off, or the beginnings of manufacturing. Primary needs will be related to infrastructure development, telecommunications, construction, power generation equipment and expertise. Education sector, health sector and other public sectors are improving slowly but surely.

Take off. Manufacturing of both semi-durable and non-durable consumer goods has begun. Goods demand is related to equipment and supplies to support manufacturing. Human resources and social standards are becoming a firm and stable system. Agriculture and industrial modernization are paving the way to a rapid expansion.

Drive to Maturity. The focus is put on low-cost manufacturing of a variety of consumer and industrial goods. The customers buy all categories of industrial products and services. The economy finds its place on the international arena. Technological and entrepreneurial skills are dominant.

Age of High Mass Production. These are countries where design activities are going on and manufacturing techniques are being developed, and they are mostly service economies, which use cutting-edge technology products. All of these lead to a change in major economies and their sectors to long-term consumers and services. Real income rises to the point where citizens get substantial amounts of discretionary income.

\section{Industrial and Consumer Markets}

There are two main factors for the similarities between the consumption of industrial and consumer goods. The first one is associated with product nature - industrial goods and services are used in the process of creating other goods and services, consumer goods are in their final form and used by individuals. The second factor - consumer motif or intention
- industrial manufacturers seek profit, whereas the end user seeks satisfaction. These factors are obvious in the schemes of supply and demand with the focus on marketing relations representing a means of competition. Regardless of whether a company is advertised in its country or abroad, special attention should be paid to differences between business-to-business and consumer markets. [5]

Along with industrial goods, business services markets have high competitor growth rate, which requires quality and value. [6] When we think in terms of international trade, we usually refer to industrial goods. The fastest growing sector of international trade in the USA is still the sector of business services - accounting, advertising, banking, consulting, construction, hospitality, insurance, legal affairs, transport and travel; all of them provided by US companies on global markets.[7] The ambiguity of services causes an array of unique problems that service providers need to address. Furthermore, the lack of equitable laws on market entry incurs even more complications. Protectionism, despite being favorable when it comes to industrial goods, can be unfavorable when it comes to providing services.

Demand in global business-to-business markets is based on exploring demand on industrial markets where high stakes are inevitable. Basically, there are three factors which affect demand on international markets and this occurs in a different way when compared to consumer markets. First, demand on industrial markets is more prominent. Second, the stages of industrial and economic development affect demand of industrial goods. Third, the technological level of product and services can make them seem more appealing in certain countries.

There are plenty of reasons why companies enter international markets - exposure to consumer demands, keeping up with competitors, expanding the life span of product manufacture, sales increase, and a higher profit. Companies providing goods and services have an additional reason for investing abroad. They invest abroad in order to prevent the natural instability on industrial markets. Perhaps one of the most important differences that can have impact on advertising of industrial and consumer goods is the changing perception of the consumers. It is true that the demand for automobiles, furniture or computers for home use can be quite volatile. However, there are two other factors that can affect both the growth and the drop of demand on industrial markets. Professional purchasers want to act promptly and accelerate changes which appear as consequences of market demand.

Industrial companies can take some measures to manage this hereditary changeability, such as maintaining a wide range of products, a swift price increase and lower advertising rates during the periods of market crash. Apart from that, market share as a strategic objective should be neglected and downsizing should be avoided with the primary focus being on market stability.

Corporation culture in most American companies comes down to beating their competition so they usually provide stability measures via their call centers. On the contrary, 
German and Japanese companies cultivate stability and their employees' well-being. Overall, they tend to overcome market instability more easily. [8]

\section{Market Demand and Technology}

An important approach to country groupings is their ability to benefit from new technologies, especially nowadays when these technologies are used as an economic advantage which enables them to skip a few stages of economic development in a short period of time. [9] Enhanced quality of education system could be the most reliable indicator of this aspect. In spite of a rather low GDP level per capita, many countries such as China, the Czech Republic and Russia highlight the importance of education. This attitude provides prospective support when it comes to applying the knowledge of technologies.

Not only is technology a key to economic success, but it also represents a competitive advantage on current global markets. Precise tasks and digital controlling systems are taking over in factories. In a similar way, manufacture is becoming more science-oriented. Consequently, cheap workforce and raw materials are becoming less important.

The ability to cultivate state-of-the-art information technology and the advantages of its application represent relevant factors regarding the international competition of managers, companies and countries. There are two closely connected global trends that result in demand for technologically advanced products. The first one is economic expansion and its industrial growth and the second one is privatization of companies that were once state-owned.

\section{Global Standards and Quality}

The technological level of a product, service standards which reflect customer needs, support service and the price compared to competition products are all part of customer perception of product quality and assessment. Customer demand differs from industrial demand. Likewise, the principles followed by large industries and customers differ and this is why they have diverse needs.

The concept of product quality is often misinterpreted on business-to-business markets. Product quality does not necessarily have to be the same on highly industrialized markets. On the other hand, good quality products can be found on less industrialized markets. [10]

\section{Buyer Determines Quality}

Product quality can be measured according to its ability to meet customer requirements. If a product fails to live up to customer expectations and lacks certain specifications, its poor quality will become obvious. However, even though it is highly unlikely, if a product exceeds its specifications, it will also indicate its scarce quality.

Product design must be contemplated in terms of its purpose and use. Product design can vary depending on current conditions in a particular region. For instance, products which are efficient in Western Europe may need to be redesigned in order to be used in the scorching Sahara desert or humid tropical rainforests in Latin America.

Due to harsh competition, companies need to offer adequate product design on a particular market. Strong competition on global markets implies that all pricy and overrated products must give way to products which can truly meet customer requirements and are far less expensive. Success lies in fulfilling every customer's needs. While some of them will look for technologically advanced products, others will look for less sophisticated ones. However, what all of them have in common is the quality they demand for the price paid.

Nowadays, keeping up with competition is a tall order. This is why a huge number of companies, the most successful ones included, communicate with their customers so as to keep informed about any changes in their needs. [11] They also take part in generating ideas about new products prior to creating a product. [12]

A lack of universal production and sales standards has become a serious issue. Modern companies, being among top exporters of industrial goods, are facing two major problems - the lack of universally accepted standards regarding the production of high quality equipment such as tools for some machines or computers; and the difficulties which arise as a consequence of using the English metric system. In the telecommunication industry, differences in standards applied across countries represent the main barrier to expansion. International agencies have put considerable effort in establishing international standards.

\section{Information Technology and Internet}

In addition, investments in information technology are the key to economic development. [9] Mobile phones, the Internet and other benefits of IT sector offer new opportunities that could help new markets to catch up with rich countries.

New and innovative electronic technologies could be essential success factors for the future of developing countries. [13] It is quite obvious that the Internet reduces the transaction costs. Lower transaction costs make it feasible for smaller companies to collaborate and develop business activities on the global market. [14] In this way, smaller companies can sell their products all around the world. One of the major benefits of prosperous economies is their availability to global customers. The economies become interrelated and more effective since transaction costs are decreased.

The Internet accelerates the process of economic development, which can be attributed to the rapid expansion 
of new technologies that are at disposal to developing countries. Countries were once expected to make a profit from railway stations, phone services or electricity. However, nowadays IT sector can significantly improve an economy and lead to high computer literacy.

A thorough assessment of economic development and marketing should first provide an insight into the basic postulates and aims of economic development. Industrialization is the primary objective of developing countries. Most countries perceive economic development as a means of achieving great results in social and state segments. What these countries look forward to is better education, efficient governments, social inequality eradication and moral and ethnic values advocacy. This is to say that economic development is not expressed through economic parameters only, but also through social achievements. [15]

Today, foreign investors are considered to be vital associates in the process of economic development. The so far experience of governments running state-owned businesses has been quite disappointing. Many countries have deregulated industry, welcomed new investments, removed the barriers and started the process of privatization.

\section{Marketing and Its Importance}

How important is the role of marketing when it comes to accomplishing the economic priorities of a country? Unfortunately, marketing is not always part of planning policy. Economic planners are increasingly production-oriented and tend to neglect distribution, which is perceived to be of minor economic importance. Generally speaking, planners are more concerned with problems related to production, investments and funds, rather than with those associated with efficient distribution.

Remaining competitive while maintaining low production costs is quite difficult to achieve even in China. Imagine a country which possesses production but no space for storage, along with limited transport, distribution to wrong markets and with no mediators who would pass the product from the manufacturer to the consumer. When such conditions are present on a developing market, marketing and economic growth are on a substantially low level and large numbers of customers are not available due to a weak or non-existent distribution network. In this case, these factors have a negative influence on economic development.

Marketing is considered to be economic mediator between productive capacity and consumer requirements. A marketing process is a critical point in using a product efficiently, which results in economic growth. Economic growth can establish a balance between higher production and higher demand. Although marketing can sometimes be perceived as a passive function, it represents a tool for efficient distribution. Efficient distribution and the channel system should comply with production capacity and customer needs. [16]
An underdeveloped economy cannot afford to invest in a sophisticated marketing strategy. Still, some efforts should be made as part of a promotion strategy. Efficient marketing strategies lead to a positive outcome.

The level of a developing market is reciprocal to its economic development. The more developed an economy is, the more necessary marketing implementation is. The evolution of channel structure illustrates the ratio between market development and the level of economic development of a country.

The development of a country is followed by the development of the distribution channel of the companies and the supply chain system. In retail sector, supermarkets and hypermarkets have emerged and have a large market share. As a consequence, the number of retail shops is decreasing, whereas sales volumes are increasing. [17]

The purpose of marketing agencies is to offer solutions for addressing the needs of expanded markets and economies. These institutions do not appear automatically or out of nowhere. One part of market research is to determine what could be beneficial in a new environment and what it takes to adapt in order to achieve the predetermined objectives. In some developing countries, retailers might be asked to introduce some basic methods of the modern marketing system.

Marketing structures in developing countries can develop simultaneously. Coming across traditional marketing, which functions as efficiently as modern retail shops, should not come as a surprise.

\section{Conclusions}

The dynamics of economic development, including the expansion of the territories of the market economies, the globalization and technological progress are just a few of the long term challenges that impose specific models of supply and demand of goods and services on the international markets. As a response to the changing marketing environment the companies restructure their business practices through outsourcing, benchmarking, partnership with the suppliers and clients, horizontal integration, shortening the supply chains, optimizing the processes and focusing on the most cost effective activities.

Global economic crisis has shown the structural weaknesses of global economy. It is obvious that economy, economic development and growth cannot function as before. The disadvantages of globalization and the demand on the global business-to-business markets can be overcome by implementing structural and institutional reforms and adopting a common trade and investment policy.

The sustainable model of more socially oriented market economies will stimulate greater productivity and international competitiveness. 


\section{REFERENCES}

[1] The term "emerging markets" is introduced by the World Bank in the 80 -ies of the last century and refers to countries characterized by social and business activities in the process of quick growth and industrialization. The classifications of reputable specialized sources and consulting groups such as The Economist, Financial Times, London Stock Exchange, MSCI and Dow Johnes, include a different number of countries. Generally the term "rapidly developing economies" is also used for emerging markets which are characterized by quick growth. In recent years new terms have appeared to describe the largest emergent markets such as BRIC that stands for Brazil, Russia, India and China, or BRICS (BRIC + South Africa), etc.

[2] More information on this topic can be found in: P. Siekman, Industrial Management and Technology, Fortune, Jan 2010 as well as in Zbornik radova sa 6-te Naučne internacionalne konferencije Ekonomija i politika, Beograd, Juni 2014, pp 33-44 and 119-133.

[3] W. Rostow, The Five Stages of Economic Growth: A Non-Communist Manifesto. Cambridge: Cambridge University Press; 1960

[4] Part of the results of the research is published in: A. Vassileva, V. Petkov, P. Zhelev, International Competitiveness of Export-oriented Industries in Bulgaria, NY: David Publishing Company, Chinese Business Review, Vol. 13, Iss:1; 2014

[5] M. Czincota, I. Ronkainen, International Marketing, Mason: Thomson South-Western; 2007
[6] F. Hardwood, Relationship Marketing, Maidenhead: McGrawHill; 2008

[7] M. Tripunoski, Menadžment vo stopanstvo i vo javniot sektor, Skopje: FON Univerzitet; 2010

[8] This issue is discussed in details in: M. Tripunoski, Globalizacija, Skopje: FON Univerzitet; 2007

[9] P. Cateora, J. Graham, International Marketing, Irwin: McGrawHill; 2007

[10] R.L. Daft, J. Murphy, H. Willmott, Organization Theory and Design, Singapore: South Western Cengage Learning; 2010

[11] F. Dwyer, Business Marketing: Connecting Strategy, Relationships and Learning, Irwin: McGrawHill; 2009

[12] A. Wilson, Service Marketing, Irwin: McGrawHill; 2008

[13] S. De Burca, R. Fletcher, L. Brown, International Marketing, Harlow: FT Prentice Hall; 2004

[14] J. Hamill, The Internet and Internet Marketing, International Marketing Review, Vol. 14, Iss:5; 1997

[15] N. Gregory Mankiw, Essentials of Economics, Mason: South Western Cengage Learning; 2007

[16] R. Sobel, J. Gwartney, R. Stroup, D. MacPherson, Understanding Economics, Mason: South Western; 2009

[17] N. Gregory Mankiw, Brief Principles of Macroeconomics, London: South Western; 2005 